\title{
Snap Bean Plant Responses to Zinc Sulfate and Manganese Sulfate Fertilization on Tile-drained Calcareous Glacial Till Soils
}

\author{
George E. MacDonald ${ }^{1}$ and Nathan H. Peck ${ }^{2}$ \\ Department of Horticultural Science, New York State Agricultural Experiment Station, Cornell \\ University, Geneva, NY 14456 \\ John Barnard ${ }^{3}$ \\ Department of Computer Services, New York State Agricultural Experiment Station, Cornell \\ University, Geneva, NY 14456 \\ Additional index words. Phaseolus vulgaris, soil test, plant tissue analysis, tile lines
}

\begin{abstract}
Effects of lateral movement of soil from tile lines based on soil and plant analysis, plus the effects of applications of $\mathrm{ZnSO}_{4}$ and $\mathrm{MnSO}_{4}$ on the concentrations of $\mathrm{Zn}, \mathrm{Mn}$, and other elements in the leaf blades of snap bean plants (Phaseolu vulgaris, var. humilis CV. Bush Blue Lake-47) and on the yield of snap bean pods at harvest were determined. Snap beans were grown across the tile lines and fertilized with five rates of $\mathrm{ZnSO}_{4}$ and $\mathrm{MnSO}_{4}$ fertilizers applied in a band at planting time. The soil decreased in $\mathrm{pH}$ and $\mathrm{Ca}$ and $\mathrm{Mn}$ content and increased in organic matter and $\mathrm{Zn}$ with distance from the tile lines. The leaf blades decreased in concentration of Ca and increased in concentrations of $\mathrm{Mg}, \mathrm{Zn}$, and $\mathrm{Mn}$ with distance from the tile lines. High rates of $\mathrm{Zn}$ and $\mathrm{Mn}$ fertilizers were required to obtain medium concentrations of $\mathrm{Zn}$ and $\mathrm{Mn}$ in plants grown over or near the tile lines. Concentrations of 24 to $30 \mu \mathrm{g}$ of $\mathrm{Zn}$ per gram dry weight and 60 to $90 \mu \mathrm{g}$ of $\mathrm{Mn}$ per gram dry weight in the leaf blades of the snap bean plants were adequate for highest yield of pods. Zinc sulfate at a rate of 0.5 to $0.7 \mathrm{~g} \mathrm{of} \mathrm{Zn} / \mathrm{m}^{2}$ produced the highest yield of pods at a distance of $3 \mathrm{~m}$ from the tile lines. Applied together, $\mathrm{ZnSO}_{4}$ and $\mathrm{MnSO}_{4}$ produced a yield response similar to application of only $\mathrm{ZnSO}_{4}$. Twenty years after installation of the tile lines, the effects of the tile lines on soil and leaf analysis and yield of pods of snap beans plants extended 2 to $3 \mathrm{~m}$ in each direction from the tile lines, indicating that the soil moved laterally.
\end{abstract}

The soils of the northeast and north central United States, derived from calcareous glacial till with rolling topography, exhibit many areas with poor internal soil drainage. As a result, thousands of hectares in these areas have had soil underdrainage systems installed to improve their productivity. Tile drainage was originated in America in 1835 by a farmer, John Johnston, on his farm located just east of Geneva, N.Y. (Vittum, 1979). Since then, many types of soil drainage systems have been installed to improve the productivity of agricultural land (Goodman, 1953; Jones, 1952). For many years, the most common method of installing tile underdrainage was by using a wheel trenching machine <Jones, 1952) to excavate a trench $\approx 0.4 \mathrm{~m}$ wide and to a depth determined by slope for drainage requirements and soil type. As tiling machines advance across a field, the surface soil, subsoil, and parent material are mixed and deposited in a berm or ridge beside the trench. After the tile is laid in the bottom of the trench, the excavated material is pushed back into the trench to cover the tile and backfill the trench.

Soils derived from calcareous glacial till have high $\mathrm{pH}$ subsoils and are low in organic matter (Cline, 1961; Secor et al., 1947). In years following tile installation, zinc deficiency symptoms frequently occur on crops, especially snap bean plants, growing over the tile lines. Chemical analysis of recently expanded leaf blades of snap bean plants growing over the tile lines revealed a $\mathrm{Zn}$ concentration $<15 \mu \mathrm{g}$ of $\mathrm{Zn} / \mathrm{g}$ of dry weight,

\footnotetext{
Received for publication 25 July, 1988. This research was partially funded by the New York State Snap Bean Research Association. The cost of publishing this paper was defrayed in part by the payment of page charges. Under postal regulations, this paper therefore must be hereby marked advertisement solely to indicate this fact.

${ }^{1}$ Research Support Specialist.

${ }^{2}$ Professor.

${ }^{3}$ Statistician.
}

the critical level established for soybeans (Ohki, 1977). The Mn concentration was low, but not in the deficient range (Piggot, 1986). During recent years the visual $\mathrm{Zn}$ deficiency symptoms on snap beans appeared to be covering an area wider than the initial tile trench, suggesting lateral movement of subsoil away from the trench. The effects of soil factors on plant availability of $\mathrm{Zn}$ are described by Tisdale and Nelson (1966) but do not include the effects of lateral movement of calcareous subsoil into adjacent areas. Studies have shown that many years of normal tillage operations caused mixing of soils across plot boundary lines in the direction of travel of the tillage equipment in long-term fertility and lime experiments (MacDonald and Peck, 1976; Ohlrogge, 1954). An experiment was designed to determine the response of snap beans to $\mathrm{ZnSO}_{4}$ and $\mathrm{MnSO}_{4}$ when grown over and between tile lines.

\section{Materials and Methods}

Five rates of $\mathrm{ZnSO}_{4}$ and $\mathrm{MnSO}_{4}(0,0.4,0.8,1.2$, and $1.6 \mathrm{~g}$ of $\mathrm{Zn}$ and $\mathrm{Mn} / \mathrm{m}^{2}$ ) were applied in a band at planting time across tile lines and the concentrations of elements in leaf blades of snap bean plants and yields of snap bean pods were determined in 1986 and 1987. Clay tile drainage lines were installed using a wheel trenching machine for fields at the Vegetable Research Farm in Geneva. The tile lines were installed in 1966 at a spacing of $15 \mathrm{~m}$ across the width of fields $60 \times 120 \mathrm{~m}$ (width/ length). The trench was $0.4 \mathrm{~m}$ wide and varied from 0.75 to $1.25 \mathrm{~m}$ in depth. The soil was a Lima silt loam (0\% to $3 \%$ slope, fine loamy, mixed mesic Glossoboric Hapludalf), a productive soil derived from calcareous glacial till. The field had had a vegetable-cover crop rotation with conventional tillage operations since 1966. On several occasions, Zn deficiency symptoms were observed on snap bean plants and other vegetables grown over the tile lines. 
Table 1. Effect of distance from the tile line on $\mathrm{pH}$, organic matter (OM), and soil elements.

\begin{tabular}{|c|c|c|c|c|c|c|c|c|}
\hline \multirow[b]{2}{*}{$\begin{array}{c}\text { Distance from tile } \\
(\mathrm{m})\end{array}$} & \multicolumn{8}{|c|}{ Soil characteristic } \\
\hline & $\mathrm{pH}$ & $\begin{array}{c}\mathrm{OM} \\
\left(\mathrm{g} \cdot \mathrm{kg}^{-1}\right) \\
\end{array}$ & $\mathrm{P}$ & $\mathrm{K}$ & $\mathrm{Ca}$ & $\mathrm{Mg}$ & $\mathrm{Zn}$ & $\mathrm{Mn}$ \\
\hline & \multicolumn{8}{|c|}{$\mathrm{mg} \cdot \mathrm{kg}^{-1} \mathrm{dry}$ wt at $0-0.25 \mathrm{~m}$ depth } \\
\hline 0.5 & 7.6 & 30.4 & 23 & 65 & 5870 & 323 & 1.2 & 30 \\
\hline 1.5 & 7.6 & 32.3 & 24 & 70 & 4600 & 305 & 0.9 & 25 \\
\hline 2.5 & 7.5 & 33.8 & 23 & 70 & 3500 & 303 & 1.1 & 21 \\
\hline 3.5 & 7.4 & 34.4 & 25 & 69 & 3030 & 310 & 1.1 & 20 \\
\hline 4.5 & 7.3 & 35.2 & 26 & 75 & 2970 & 318 & 1.3 & 21 \\
\hline 5.5 & 7.3 & 35.0 & 26 & 74 & 2970 & 313 & 1.4 & 21 \\
\hline \multicolumn{9}{|l|}{ Significance } \\
\hline Distance & $<0.01$ & $<0.01$ & 0.38 & 0.01 & $<0.01$ & 0.86 & 0.11 & $<0.01$ \\
\hline Linear & $<0.01$ & $<0.01$ & 0.08 & $<0.01$ & $<0.01$ & 0.95 & 0.03 & $<0.01$ \\
\hline Quadratic & 0.74 & 0.02 & 0.87 & 0.74 & $<0.01$ & 0.37 & 0.13 & $<0.01$ \\
\hline $\mathrm{CV} \%$ & 2 & 3 & 10 & 5 & 14 & 8 & 20 & 13 \\
\hline
\end{tabular}

Table 2. Effects of distance from the tile line, rates of $\mathrm{ZnSO}_{4}$ and $\mathrm{MnSO}_{4}$ fertilizers, and $\mathrm{Zn}$ and $\mathrm{Mn}$ treatments on the concentrations of $\mathrm{P}, \mathrm{K}, \mathrm{Ca}$, and $\mathrm{Mg}$ in leaf blades of snap beans at flowering.

\begin{tabular}{|c|c|c|c|c|}
\hline \multirow[b]{2}{*}{ Criterion } & \multicolumn{4}{|c|}{ Concn of elements $\left(\mathrm{mg} \cdot \mathrm{g}^{-1}\right.$ dry $\left.\mathrm{wt}\right)$} \\
\hline & $\underline{P}$ & $\mathrm{~K}$ & $\mathrm{Ca}$ & $\mathrm{Mg}$ \\
\hline \multicolumn{5}{|c|}{ Distance from tile $(\mathrm{m})^{\mathrm{z}}$} \\
\hline 0.5 & 3.0 & 16.9 & 22.6 & 3.9 \\
\hline 1.5 & 3.0 & 17.0 & 22.1 & 4.3 \\
\hline .2 .5 & 3.0 & 17.0 & 21.6 & 4.6 \\
\hline 3.5 & 2.9 & 15.7 & 20.9 & 4.7 \\
\hline 4.5 & 2.9 & 15.9 & 20.3 & 4.6 \\
\hline 5.5 & 2.8 & 16.3 & 19.4 & 4.4 \\
\hline \multicolumn{5}{|l|}{ Rate $\left(g \cdot m^{-2}\right)^{y}$} \\
\hline $0.0^{101}$ & 3.1 & 16.7 & 21.4 & 4.6 \\
\hline 0.4 & 3.0 & 16.6 & 21.1 & 4.5 \\
\hline 0.8 & 3.0 & 16.3 & 21.1 & 4.5 \\
\hline 1.2 & 2.8 & 16.6 & 20.6 & 4.2 \\
\hline 1.6 & 2.9 & 16.4 & 21.7 & 4.6 \\
\hline \multicolumn{5}{|l|}{$(\mathrm{Zn})^{\mathrm{x}}$} \\
\hline$-\mathrm{Zn}$ & 3.1 & 16.8 & 21.4 & 4.6 \\
\hline$+\mathrm{Zn}$ & 2.8 & 16.1 & 20.8 & 4.3 \\
\hline \multicolumn{5}{|l|}{$\mathrm{Mn}^{\mathrm{w}}$} \\
\hline$-M n$ & 3.0 & 16.4 & 21.3 & 4.5 \\
\hline$+\mathrm{Mn}$ & 2.9 & 16.5 & 21.0 & 4.4 \\
\hline \multicolumn{5}{|l|}{ Significance } \\
\hline Distance & 0.54 & 0.48 & $<0.01$ & $<0.01$ \\
\hline Linear & 0.11 & 0.14 & $<0.01$ & $<0.01$ \\
\hline Quadratic & 0.30 & 0.75 & 0.63 & $<0.01$ \\
\hline $\mathrm{CV} \%$ & 7 & 7 & 4 & 3 \\
\hline Rate & 0.02 & 0.70 & 0.19 & $<0.01$ \\
\hline Linear & 0.12 & 0.73 & 0.36 & 0.92 \\
\hline Quadratic & 0.42 & 1.00 & 0.14 & 0.04 \\
\hline $\mathrm{CV} \%$ & 8 & 7 & 8 & 7 \\
\hline $\mathrm{Zn}$ & $<0.01$ & $<0.01$ & 0.04 & $<0.01$ \\
\hline Distance $\times \mathrm{Zn}$ & 0.29 & $<0.01$ & 0.28 & 0.17 \\
\hline $\mathrm{CV} \%$ & 10 & 7 & 9 & 8 \\
\hline $\mathrm{Mn}$ & 0.71 & 0.22 & 0.16 & 0.68 \\
\hline $\mathrm{CV} \%$ & 10 & 9 & 12 & 9 \\
\hline
\end{tabular}

${ }^{z}$ Combined rates $\times \mathrm{Zn} \times \mathrm{Mn}$ treatments $\times$ replications.

${ }^{y}$ Combined distances $\times \mathrm{Zn} \times$ Mn treatments $\times$ replications.

${ }^{x}$ Combined distances $\times$ rates $\times$ Mn treatments $\times$ replications.

${ }^{\mathrm{w}}$ Combined distances $\times$ rates $\times \mathrm{Zn}$ treatments $\times$ replications.

'Bush Blue Lake-47' snapbeans were grown in 1986 and 1987. Seeds were planted on 28 May 1986 and on 11 June 1987. The cultural practices, seed treatment, and herbicide applications have been described (Peck et al., 1989). Fertilizer $\mathrm{Zn}$ from $\mathrm{ZnSO}_{4}$ and $\mathrm{Mn}$ from $\mathrm{MnSO}_{4}$ were applied at elemental rates of $0,0.2,0.4,0.6$, and $0.8 \mathrm{~g}$ per meter of row in rows $0.5 \mathrm{~m}$ apart $\left(0,0.4,0.8,1.2\right.$, and $\left.1.6 \mathrm{~g} \cdot \mathrm{m}^{-2}\right)$ in a band $5 \mathrm{~cm}$ to the side and $\overline{5} \mathrm{~cm}$ below the depth of the seed at planting for each year. The experimental design was a split plot with rates as main plots and with a two-level $\mathrm{Mn} \times \mathrm{Zn}$ factorial as subplots within each main plot. Rates were randomized within blocks, while the $\mathrm{Zn} \times \mathrm{Mn}$ factorial was randomized as Latin squares within the rates. An identical experiment was repeated in 1987 in the same field, with plots established not to overlap the plots of the previous year. There were two complete replications of main plots and subplots each year. Each main plot, $2 \times 60 \mathrm{~m}$ (width/length), consisted of four differently treated rows (no $\mathrm{Zn}$ or $\mathrm{Mn}, \mathrm{Zn}, \mathrm{Mn}$, and $\mathrm{Zn}$ plus $\mathrm{Mn}$ ) $0.5 \mathrm{~m}$ apart on a level bed perpendicular to the tile lines. Wheel tracks of the tractor and the planter were outside the edge of each plot. All plots received constant rates of $\mathrm{N}, \mathrm{P}$, and $\mathrm{K}$ at $5 \mathrm{~g} \cdot \mathrm{m}^{-2}(2.5 \mathrm{~g}$ per meter of row) for each element from a blend consisting of mono-ammonium phosphate (MAP), $\mathrm{NH}_{4} \mathrm{NO}_{3}\left(\mathrm{NH}_{4}\right)_{2} \mathrm{SO}_{4}, \mathrm{KCl}$, and potassium-magnesium sulfate in a band at planting time. MAP supplied $2.4 \mathrm{~g}$ of $\mathrm{N} / \mathrm{m}^{2}$, the remaining $2.6 \mathrm{~g}$ of $\mathrm{N} / \mathrm{m}^{2}$ was supplied equally from $\mathrm{NH}_{4} \mathrm{NO}_{3}$ and $\left(\mathrm{NH}_{4}\right)_{2} \mathrm{SO}_{4}\left(1.3 \mathrm{~g}\right.$ of $\mathrm{N} / \mathrm{m}^{2}$ from each source), and each $\mathrm{K}$ source supplied $2.5 \mathrm{~g}$ of $\mathrm{K} / \mathrm{m}^{2}$.

Soil samples were taken each year from each main plot to a $0.25-\mathrm{m}$ depth at meter intervals starting from the center of randomly selected tile lines to a lateral distance of $6 \mathrm{~m}$ in each direction. The soil samples taken in July 1986 and June 1987 were analyzed for $\mathrm{P}, \mathrm{K}, \mathrm{Ca}, \mathrm{Mg}, \mathrm{Mn}$, and $\mathrm{Zn}$, using ammonium acetate-acetic acid extracting solution adjusted to $\mathrm{pH} 4.8$ (MacDonald et al., 1978). Soil pH was determined in a 1 soil :1 water (w/w) ratio and organic matter was determined by the titrimetric method (Greweling and Peech, 1965).

Plant tissue samples were taken on 8 to 10 July 1986 and on 21 July 1987 for chemical analysis. Blades of eight recently fully expanded trifoliate leaves of the snap bean plants were taken from each subplot at $1-m$ intervals starting at the center of the same tile line used for the soil samples and extending to a distance of $6 \mathrm{~m}$ in both directions from the sides of the tile lines. Samples were rinsed in demineralized water, blotted dry, placed in white paper bags, and dried in a forced-air drying oven at $70 \mathrm{C}$ for $48 \mathrm{hr}$. Oven-dried leaf blade samples were ground in a stainless steel Wiley mill using a $850 \mu \mathrm{m}$ screen, dry ashed, and analyzed for P, K, Ca, Mg, Zn, and Mn (Grew- 

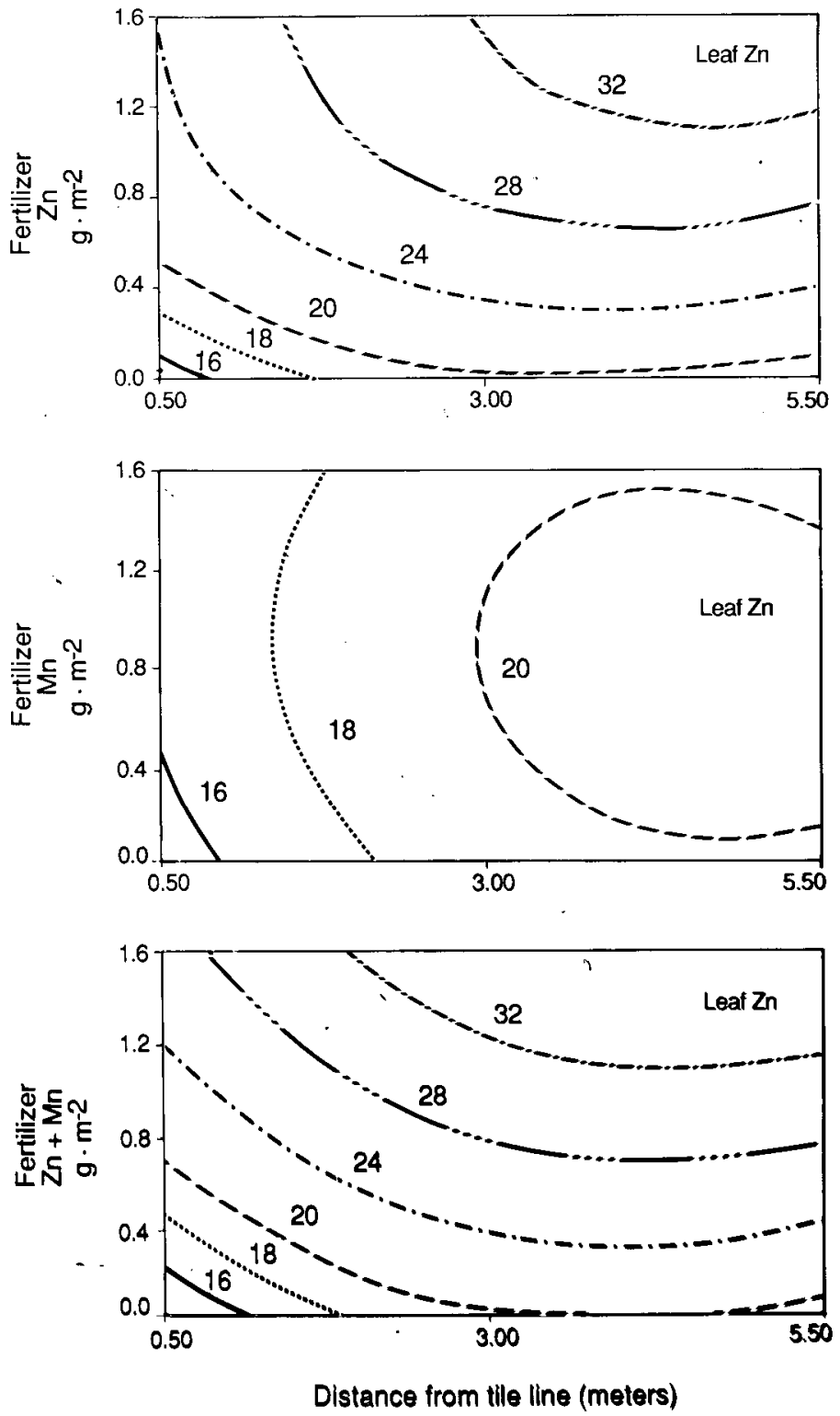

Fig. 1. Concentration of $\mathrm{Zn}\left(\mu \mathrm{g} \cdot \mathrm{g}^{-1}\right.$ dry weight) isoquants in leaf blades of snap bean plants at bloom stage for interaction of rates of $\mathrm{Zn}$ from $\mathrm{ZnSO}_{4}$ and $\mathrm{Mn}$ from $\mathrm{MnSO}_{4}$ (grams of $\mathrm{Zn}$ and $\mathrm{Mn} / \mathrm{m}^{2}$ ) and for distance from the tile line (m) (see Table 4).

eling, 1976) except that the residue of salts was dissolved in $1.0 \mathrm{~N} \mathrm{HC}$. Phosphorus was determined by the molybdvanado $\mathrm{H}_{3} \mathrm{PO}_{4}$ procedure (Greweling, 1976). Potassium was determined in the emission made of a Jarrell-Ash Dial Atom-III atomic absorption spectrophotometer (Therma Jarrell Ash, Waltham, Mass.) Calcium and magnesium were determined by atomic absorption after addition of lanthanum solution, while $\mathrm{Zn}$ and Mn were determined directly by atomic absorption (Greweling, 1976).

Pods were not harvested in 1986 because of heavy rains at harvest time. In 1987 pods were harvested 6 Aug. Pods were hand-picked from l-m sections of row from each subplot at 0 to $1 \mathrm{~m}, 3$ to $4 \mathrm{~m}$, and 5 to $6 \mathrm{~m}$ from the center of the tile line. Pods were separated into sieve-size grades by a Chisholm-Ryder double adjustable bar type grader (Peck and Van Buren, 1975).

GENSTAT (Lawes Agricultural Trust, Rothamsted Experiment Station, U.K.) was used to compute the analysis of variance for the level of significance and the regressions partitioned
Table 3. Effects of distance from the tile line, rates of $\mathrm{ZnSO}_{4}$ and $\mathrm{MnSO}_{4}$ fertilizers, and $\mathrm{Zn}$ and $\mathrm{Mn}$ treatment on the concentration of $\mathrm{Zn}$ and $\mathrm{Mn}\left(\mu \mathrm{g} \cdot \mathrm{g}^{-1}\right.$ dry wt) in leaf blades of snap beans at flowering.

\begin{tabular}{|c|c|c|c|}
\hline \multirow[b]{2}{*}{ Criterion } & \multicolumn{3}{|c|}{ Concn of elements } \\
\hline & $\mathrm{Zn}$ & & $\mathrm{Mn}$ \\
\hline \multicolumn{4}{|c|}{ Distance from tile $(\mathrm{m})^{z}$} \\
\hline 0.5 & 19 & & 50 \\
\hline 1.5 & 21 & & 54 \\
\hline 2.5 & 24 & & 79 \\
\hline 3.5 & 25 & & 91 \\
\hline 4.5 & 25 & & 87 \\
\hline 5.5 & 25 & & 80 \\
\hline \multicolumn{4}{|l|}{ Rate $\left(\mathrm{g} \cdot \mathrm{m}^{-2}\right)^{y}$} \\
\hline $0.0^{\circ}$ & 18 & & 60 \\
\hline 0.4 & 20 & & 64 \\
\hline 0.8 & 24 & $\ldots$ & 73 \\
\hline 1.2 & 23 & & 77 \\
\hline 1.6 & 25 & & 79 \\
\hline \multicolumn{4}{|l|}{$\mathrm{Zn}^{\mathrm{x}}$} \\
\hline$-\mathrm{Zn}$ & 18 & & 75 \\
\hline$+\mathrm{Zn}$ & 28 & & 72 \\
\hline \multicolumn{4}{|l|}{$\mathrm{Mn}^{\mathrm{w}}$} \\
\hline$-\mathrm{Mn}$ & 23 & & 60 \\
\hline$+\mathrm{Mn}$ & 23 & & 87 \\
\hline \multicolumn{4}{|l|}{ Significance } \\
\hline Distance & 0.09 & & $<0.01$ \\
\hline Linear & $<0.01$ & & $<0.01$ \\
\hline Quadratic & 0.15 & & $<0.01$ \\
\hline $\mathrm{CV} \%$ & 14 & & 16 \\
\hline Rate & $<0.01$ & & $<0.01$ \\
\hline Linear & $<0.01$ & & $<0.01$ \\
\hline Quadratic & 0.04 & & 0.15 \\
\hline $\mathrm{CV} \%$ & 13 & & 17 \\
\hline $\mathrm{Zn}$ & $<0.01$ & & 0.20 \\
\hline Rate $\times \mathrm{Zn}_{\mathrm{n}}$ & $<0.01$ & & 0.38 \\
\hline $\mathrm{CV} \%$ & 23 & & 20 \\
\hline $\mathrm{Mn}$ & 0.24 & & $<0.01$ \\
\hline Rate $\times \mathrm{Mn}$ & 0.13 & & $<0.01$ \\
\hline $\mathrm{Cv} \%$ & 18 & & 28 \\
\hline
\end{tabular}

${ }^{\mathrm{z}}$ Combined rates $\times \mathrm{Zn} \times \mathrm{Mn}$ treatments $\times$ replications.

${ }^{y}$ Combined distances $\times \mathrm{Zn} \times$ Mn treatments $\times$ replications. ${ }^{\times}$Combined distances $\times$rates $\times$Mn treatments $\times$replications.

${ }^{\text {w }}$ Combined distances $\times$ rates $\times$ Zn treatments $\times$ replications.

to linear and quadratic responses in the order given. MINITAB (Minitab, University Park, Pa.) was used for the regression analysis. Figures 1 through 4 were produced using the GCONTOUR procedure of SAS/GRAPH (SAS Institute, Cary, N.C.).

\section{Results and Discussion}

Weather and years. The growing season weather during 1986 and 1987 was similar. There were few interactions with $P \leqslant$ 0.01 among years $\times$ distance from the tile lines $\times$ rates of $\mathrm{Zn}$ and Mn fertilizers on the concentrations of elements in the leaf blades at flowering. The year effect was very slight on soil test results. Thus, the results given are for combined years.

Soil tests. Soil $\mathrm{pH}$ decreased gradually with distance from the tile lines, while soil organic matter increased with distance (Table 1). Soil K consistently and $\mathrm{Zn}$ generally increased with distance from the tile lines. Soil $\mathrm{Ca}$ declined rapidly with distance from the tile lines, while distance had no effect on soil Mg (Table 1). Soil Mn decreased with distance from the tile lines. Thus, soil Mn increased as soil $\mathrm{pH}$ increased as measured by the soil test method used. Our previous results (unpublished 
Table 4. Regression equations for concentrations of $\mathbf{Z n}\left(\mu \mathrm{g} \cdot \mathrm{g}^{-1} \mathrm{dry}\right.$ wt) in leaf blades of snap bean plants at bloom stage for rates (R) of $\mathrm{Zn}$ from $\mathrm{ZnSO}_{4}$ and $\mathrm{Mn}$ from $\mathrm{MnSO}_{4}$ (grams of $\mathrm{Zn}$ and $\mathrm{Mn} / \mathrm{m}^{2}$ ) and for distance (D) from the tile line $(\mathrm{m})^{\mathrm{z}}$.

\begin{tabular}{|c|c|c|c|c|c|c|c|c|}
\hline \multicolumn{9}{|l|}{$\mathrm{Zn}$ rates } \\
\hline $\mathrm{Zn}\left(\mu \mathrm{g} \cdot \mathrm{g}^{-1}\right)$ & $=13.0+$ & $3.57 \mathrm{D}+$ & + & $11.7 \mathrm{R}$ & - & $0.479 \mathrm{D}^{2}$ & $-3.94 R^{2}$ & $+0.86 \mathrm{R} \times \mathrm{D}$ \\
\hline SD & - 1.9 & 1.1 & & 3.0 & & 0.2 & 1.6 & 0.4 \\
\hline$P$ value & & $<0.01$ & . & $<0.01$ & & 0.01 & 0.02 & 0.07 \\
\hline \multicolumn{9}{|l|}{ Mn rates } \\
\hline $\mathrm{Zn}\left(\mu \mathrm{g} \cdot \mathrm{g}^{-1}\right)$ & $=14.0+$ & $2.45 \mathrm{D}+$ & + & $2.83 \mathrm{R}$ & - & $0.26 \mathrm{D}^{2}$ & $-1.41 \mathrm{R}^{2}$ & $-0.12 \mathrm{R} \times \mathrm{D}$ \\
\hline SD & 0.8 & 0.5 & & 1.3 & & 0.1 & 0.7 & 0.2 \\
\hline$P$ value & & $<0.01$ & & 0.04 & & $<0.01$ & 0.05 & 0.53 \\
\hline \multicolumn{9}{|l|}{$\mathrm{Zn}+\mathrm{Mn}$ rates } \\
\hline $\mathrm{Zn}\left(\mu \mathrm{g} \cdot \mathrm{g}^{-1}\right)$ & $=11.9+$ & $4.26 \mathrm{D}+$ & + & $10.1 \mathrm{R}$ & - & $0.54 \mathrm{D}^{2}$ & $-1.49 R^{2}$ & $+0.56 \mathrm{R} \times \mathrm{D}$ \\
\hline & 2.4 & 1.4 & & 3.7 & & 0.2 & 2.0 & 0.6 \\
\hline$P$ value & & $<0.01$ & & 0.01 & & 0.02 & 0.46 & 0.32 \\
\hline
\end{tabular}

${ }^{z_{n}}=30 ; \mathrm{SD}=$ standard deviation.

Table 5. Regression equations for concentrations of $\mathrm{Mn}\left(\mu \mathrm{g}: \mathrm{g}^{-1}\right.$ dry wt) in leaf blades of snap bean plants at bloom stage for rates $\left(\mathrm{R}\right.$ ) of $\mathrm{Zn}$ from $\mathrm{ZnSO}_{4}$ and $\mathrm{Mn}$ from $\mathrm{MnSO}_{4}$ (grams of $\mathrm{Zn}$ and $\mathrm{Mnt}$ $\mathrm{m}^{2}$ ) and for distance (D) from the tile line $(\mathrm{m})^{\mathrm{x}}$.

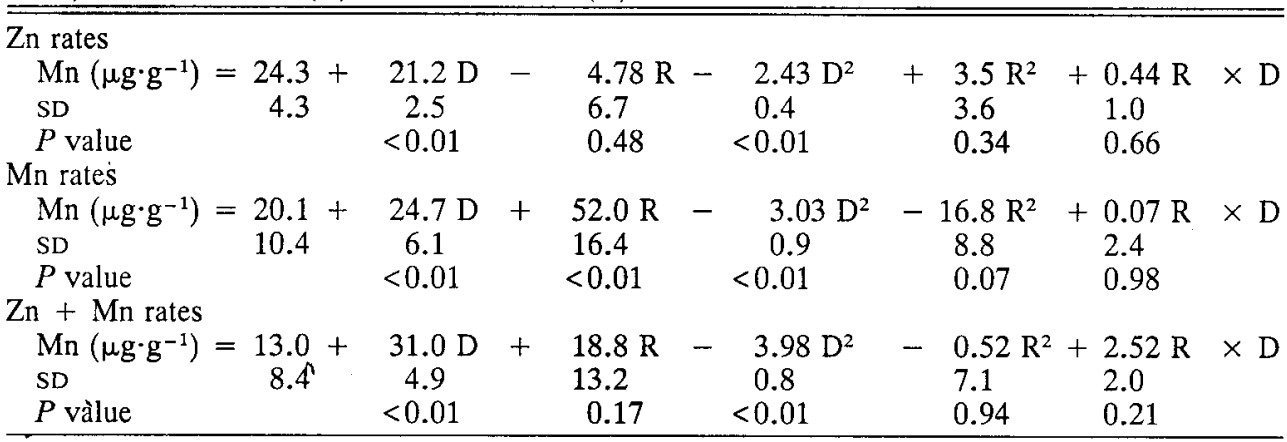

${ }^{z} \mathbf{n}=30 ; \mathrm{SD}=$ standard deviation.

Table 6. Regression equations for yield of snap bean pods (grams fresh $\mathrm{wt} / \mathrm{m}^{2}$ ) for rates

(R) of $\mathrm{Zn}$ from $\mathrm{ZnSO}_{4}$ and $\mathrm{Mn}$ from $\mathrm{MnSO}_{4}$ (grams of $\mathrm{Zn}$ and $\mathrm{Mn} / \mathrm{m}^{2}$ ) and for distance

(D) from the tile line $(\mathrm{m})^{\mathrm{z}}$.

\begin{tabular}{|c|c|c|c|c|c|c|c|}
\hline \multicolumn{8}{|l|}{$\mathrm{Zn}$ rates } \\
\hline Yield of pods & $=1110+$ & $167 \mathrm{D}$ & $+527 \mathrm{R}$ & $-20 \mathrm{D}^{2}$ & $-231 R^{2}$ & $-66 R$ & $\times \mathrm{D}$ \\
\hline SD & 123 & 74 & 226 & 12 & 124 & 29 & \\
\hline$\dot{P}$ value & & 0.05 & 0.04 & 0.13 & 0.10 & 0.05 & \\
\hline \multicolumn{8}{|l|}{ Mn rates } \\
\hline Yield of pods & $=1199$ & $2 \mathrm{D}$ & $-143 \mathrm{R}$ & $+11.9 \mathrm{D}^{2}$ & $+204 R^{2}$ & $-45 R$ & $\times \mathrm{D}$ \\
\hline SD & 152 & 91 & 277 & 14 & 152 & 35 & \\
\hline$P$ value & & 0.98 & 0.62 & 0.43 & 0.21 & 0.23 & \\
\hline \multicolumn{8}{|l|}{$\mathrm{Zn}+\mathrm{Mn}$ rates } \\
\hline Yield of pods & $=1176+$ & $208 \mathrm{D}$ & $+282 \mathrm{R}$ & $-32 D^{2}$ & $-\quad 77 \mathrm{R}^{2}$ & $-50 \mathrm{R}$ & $\times \mathrm{D}$ \\
\hline SD & 119 & 72 & 217 & 11 & 119 & 27 & \\
\hline$P$ value & & 0.02 & 0.23 & 0.02 & 0.53 & 0.10 & \\
\hline
\end{tabular}

${ }^{z_{n}}=15 ; \mathrm{SD}=$ standard deviation.

data) and those reported by Mohebbi and Mahler (1988) showed that soil Mn decreased with increasing soil pH. Krauskopf (1967) showed that of the sedimentary rocks, limestone had the highest concentration of $\mathrm{Mn}$. The soil-extracting solution, ammonium acetate-acetic acid adjusted to $\mathrm{pH} 4.8$, extracted $\mathrm{Mn}$ in proportion to the amount of limestone, especially near the tile lines.

The increase in soil organic matter was primarily a dilution effect, as Secor et al. (1947) showed organic matter in the soil decreased with depth. Peck et al. (1976) showed soil P and K decreased with depth regardless of past fertilization practices. Soil Ca was affected by distance from the tile lines more than any other soil variable, showing a large decrease with distance from the tile line, while soil $\mathrm{pH}$ gradually declined with distance (Table 1). Soil $\mathrm{pH}$ of soils derived from calcareous glacial till depends on the $\mathrm{CO}_{2}$ pressure in the soil air (Bradfield, 1941). Soil $\mathrm{Zn}$ values were variable, displaying a $20 \% \mathrm{cv}$ (Table 1).
Incomplete backfill from the berm side of the trench could account for distance effects on the soil test results; however, the soil was sampled in both directions from the tile lines with no effects of direction on the results. Thus, the soil tests indicated lateral movement of the soil from the tile lines during the 20 years following installation, and the lateral movement extended 2 to $3 \mathrm{~m}$ in each direction from the tile lines.

$P, K, C a$, and $\mathrm{Mg}$ in leaf blades. The concentration of $\mathrm{P}$ in the leaf blades was not affected by distance from the tile lines (Table 2). Fertilizer $\mathrm{Zn}$ from $\mathrm{ZnSO}_{4}$ decreased the concentration of $\mathrm{P}$ in the leaf blades. Jackson et al. (1967) reported a P vs. Zn effect on sweet corn (Zea mays L.), especially on plots that received applications of lime, and explained the effect as a dilution due to the greater yield of the combined lime-Zn treatment. The concentration of $\mathrm{K}$ (Table 2) in the leaf blades was not affected by distance from the tile lines but was decreased 

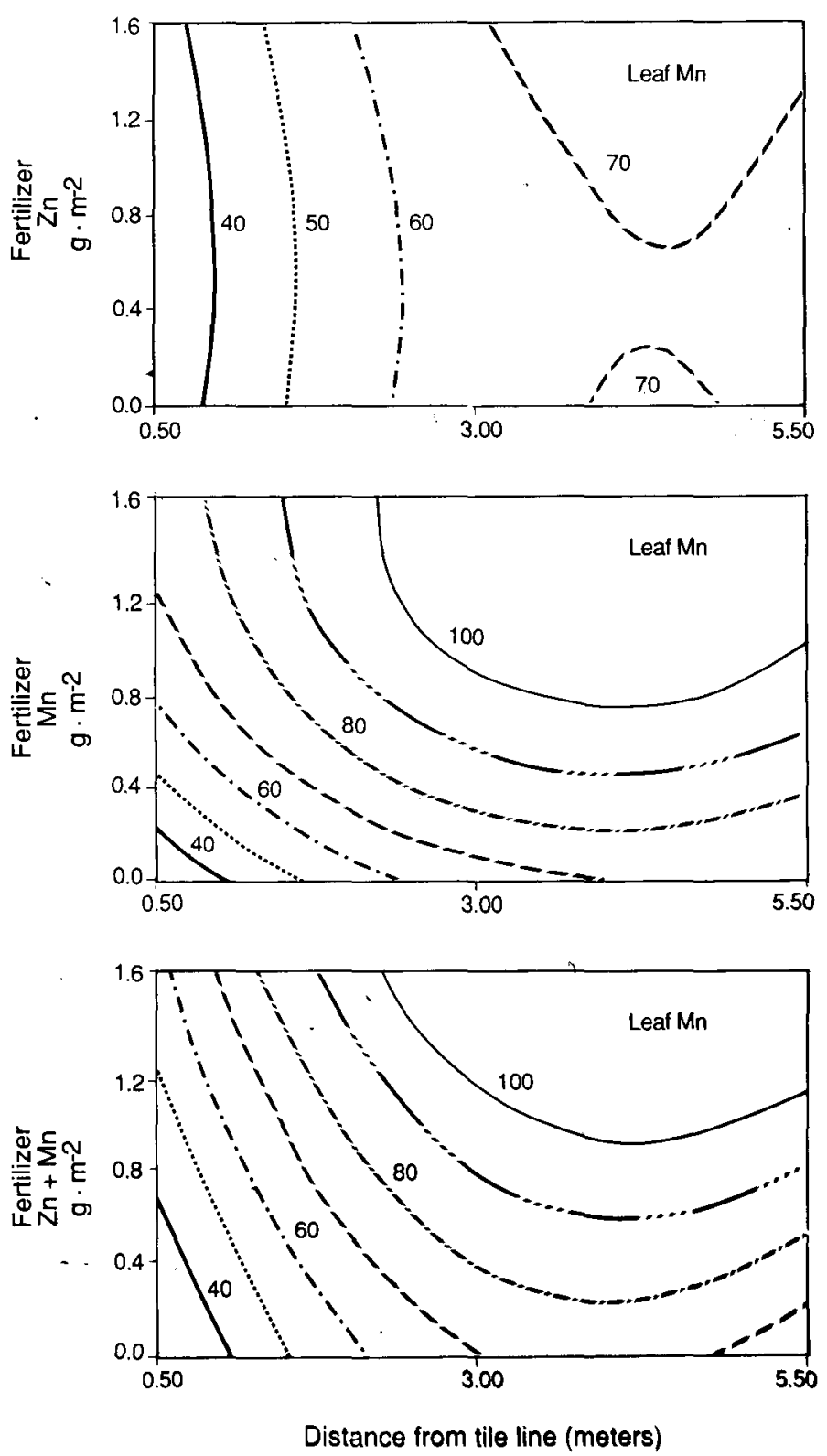

Fig. 2. Concentration of $\mathrm{Mn}\left(\mu \mathrm{g} \cdot \mathrm{g}^{-1}\right.$ dry weight) isoquants in leaf blades of snap bean plants at bloom stage for interaction of rates of $\mathrm{Zn}$ from $\mathrm{ZnSO}_{4}$ and $\mathrm{Mn}$ from $\mathrm{MnSO}_{4}$ (grams of $\mathrm{Zn}$ and $\mathrm{Mn} / \mathrm{m}^{2}$ ) and for distance from the tile line $(\mathrm{m})$ (see Table 5).

slightly by an application of fertilizer $\mathrm{Zn}$. Application of $\mathrm{Zn}$ fertilizer and distance interacted with the concentration of $\mathrm{K}$ in the leaf blades. Without $\mathrm{Zn}$ fertilizer, the $\mathrm{K}$ concentration decreased with distance, but with $\mathrm{Zn}$ fertilizer the K concentration remained constant with distance from the tile lines (data not shown). The concentration of $\mathrm{Ca}$ (Table 2) was influenced by distance from the tile lines, more than from applications of $\mathrm{Zn}$ fertilizer, decreasing with distance while $\mathrm{Zn}$ fertilizer had a slight effect. Soil $\mathrm{Ca}$ was highest at or near the tile line (Table 1). The concentration of $\mathrm{Mg}$ increased with distance from the tile line, while application of $\mathrm{Zn}$ fertilizer decreased the concentration of $\mathrm{Mg}$ even though all plots received a uniform band application of $2.5 \mathrm{~g} \mathrm{Mg} / \mathrm{m}^{2}$ from potassium-magnesium sulfate. Fertilizer $\mathrm{Mn}$ from $\mathrm{MnSO}_{4}$ had no effect on the concentration of $\mathrm{P}, \mathrm{K}, \mathrm{Ca}$, and $\mathrm{Mg}$ in the leaf blades (Table 2). The concentrations of $\mathrm{P}, \mathrm{K}, \mathrm{Ca}$, and $\mathrm{Mg}$ in the leaf blades were affected
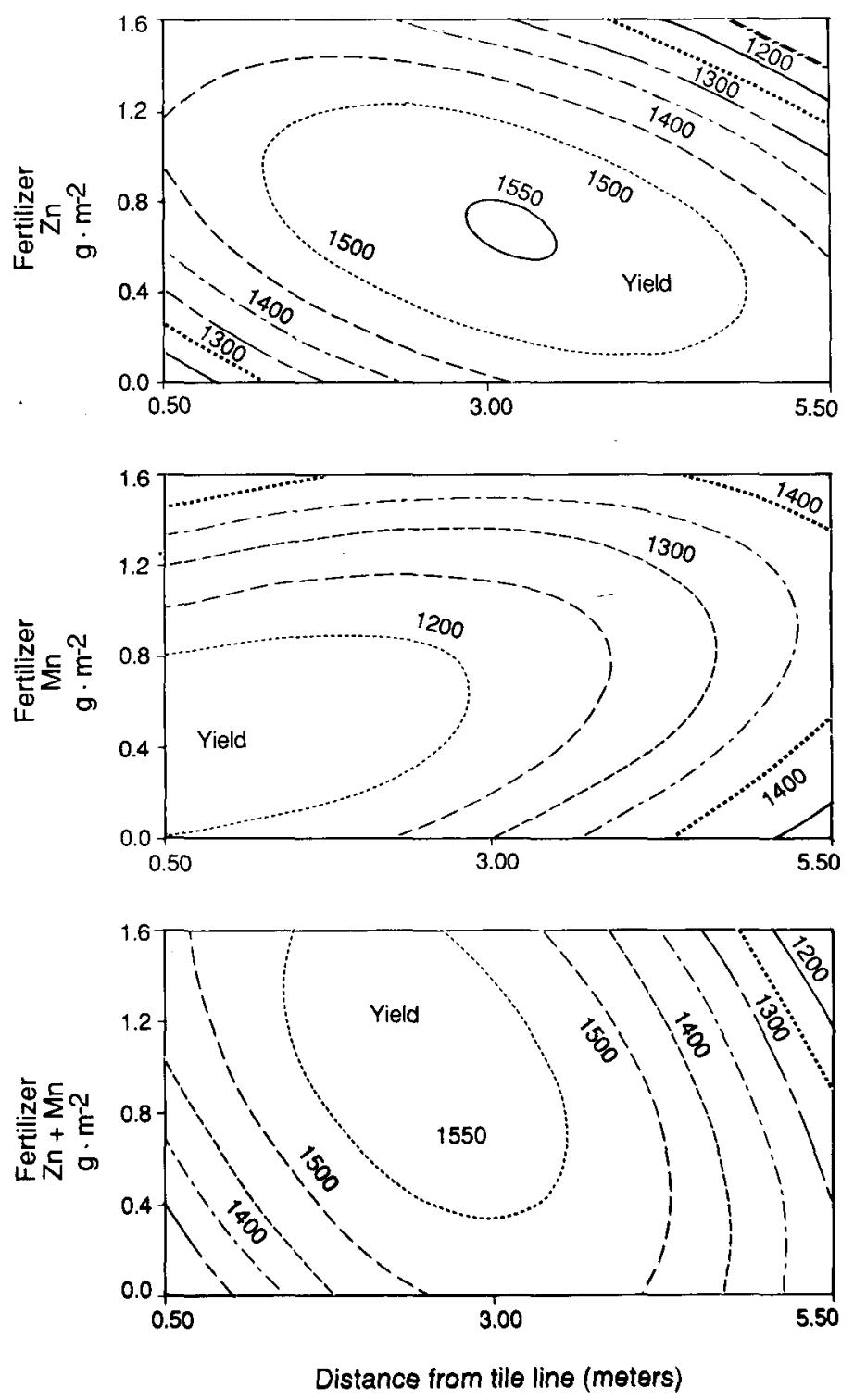

Fig. 3. Yield isoquants ( $\mathrm{g}$ fresh weight $/ \mathrm{m}^{2}$ ) of snap bean pods for interaction of rates of $\mathrm{Zn}$ from $\mathrm{ZnSO}_{4}$ and $\mathrm{Mn}$ from $\mathrm{MnSO}_{4}$ (grams of $\mathrm{Zn}$ and $\mathrm{Mn} / \mathrm{m}^{2}$ ) and for distance from the tile line $(\mathrm{m}$ ) (see Table $6)$.

by the highly calcareous subsoil at or near the tile lines and by applications of fertilizer $\mathrm{Zn}$.

$\mathrm{Zn}$ and $\mathrm{Mn}$ in leaf blades. Increasing rates of $\mathrm{ZnSO}_{4}$ fertilizer caused an increase in the concentration of $\mathrm{Zn}$ in the leaf blades (Table 3). The concentration of $\mathrm{Zn}$ in the leaf blades as a function of rates of $\mathrm{ZnSO}_{4}$ and distance from the tile lines showed that this concentration depended on both rate and distance (Fig. 1, Table 4). The concentration of $\mathrm{Zn}$ in the leaf blades as a function of rates of $\mathrm{MnSO}_{4}$ and distance from the tile line showed that the concentration of $\mathrm{Zn}$ in the leaf blades was most dependent on distance (Fig. 1, Table 4). When $\mathrm{Zn}$ and $\mathrm{Mn}$ were applied together, the concentration of $\mathrm{Zn}$ in the leaf blades depended on both rate and distance from the tile lines (Fig. 1, Table 4).

Applications of $\mathrm{Zn}$ and $\mathrm{Mn}$ fertilizers together caused an increase in the concentration of $\mathrm{Zn}$ in the leaf blades at $0.5 \mathrm{~m}$ from the tile lines more than $\mathrm{Zn}$ alone. A rate of $>1.6 \mathrm{~g}$ of $\mathrm{Zn} /$ $\mathrm{m}^{2}$ was required to obtain a concentration of $24 \mu \mathrm{g}$ of Zn dry weight in the blades when applied alone, while only $1.2 \mathrm{~g}$ of 
Table 7. Regression equations for size of pods (percent of pods sieve-size 4 and under) for rates $(R)$ of $\mathrm{Zn}$ from $\mathrm{ZnSO}_{4}$ and $\mathrm{Mn}$ from $\mathrm{MnSO}_{4}$ (grams of $\mathrm{Zn}$ and $\mathrm{Mn} / \mathrm{m}^{2}$ ) and for distance $(D)$ from the tile line $(m)^{2}$.

\begin{tabular}{|c|c|c|c|c|c|}
\hline \multicolumn{6}{|l|}{$\mathrm{Zn}$ rates } \\
\hline$\% 4 \mathrm{~s}$ and under $=85.5$ & $-0.84 \mathrm{D}$ & $-5.20 \mathrm{R}$ & $-0.48 D^{2}$ & $+2.92 R^{2}$ & $+0.06 \mathrm{R} \times \mathrm{D}$ \\
\hline $\mathrm{SD}$ & 2.6 & 7.8 & 0.4 & 4.3 & 1.0 \\
\hline$P$ value & 0.75 & 0.52 & 0.27 & 0.51 & 0.95 \\
\hline \multicolumn{6}{|l|}{ Mn rates } \\
\hline$\% 4 \mathrm{~s}$ and under $=86.7$ & $-1.60 \mathrm{D}$ & $-7.27 \mathrm{R}$ & $+0.02 D^{2}$ & $+3.15 \mathrm{R}^{2}$ & $+0.27 \mathrm{R} \times \mathrm{D}$ \\
\hline SD 2.5 & 1.5 & 4.6 & 0.2 & 2.5 & 0.6 \\
\hline$P$ value & 0.31 & 0.14 & 0.95 & 0.24 & 0.65 \\
\hline \multicolumn{6}{|l|}{$\mathrm{Zn}+\mathrm{Mn}$ rates } \\
\hline$\% 4 \mathrm{~s}$ and under $=86.8$ & $-2.92 \mathrm{D}$ & $-5.86 \mathrm{R}$ & $+0.26 D^{2}$ & $+4.48 \mathrm{R}^{2}$ & $-0.52 \mathrm{R} \times \mathrm{D}$ \\
\hline $\mathrm{SD} \quad 4.4$ & 2.6 & 8.0 & 0.4 & 4.4 & 1.0 \\
\hline$P$ value & 0.30 & 0.48 & 0.55 & 0.34 & 0.62 \\
\hline
\end{tabular}

$\mathrm{z}_{\mathrm{n}}=15 ; \mathrm{SD}=$ standard deviation.
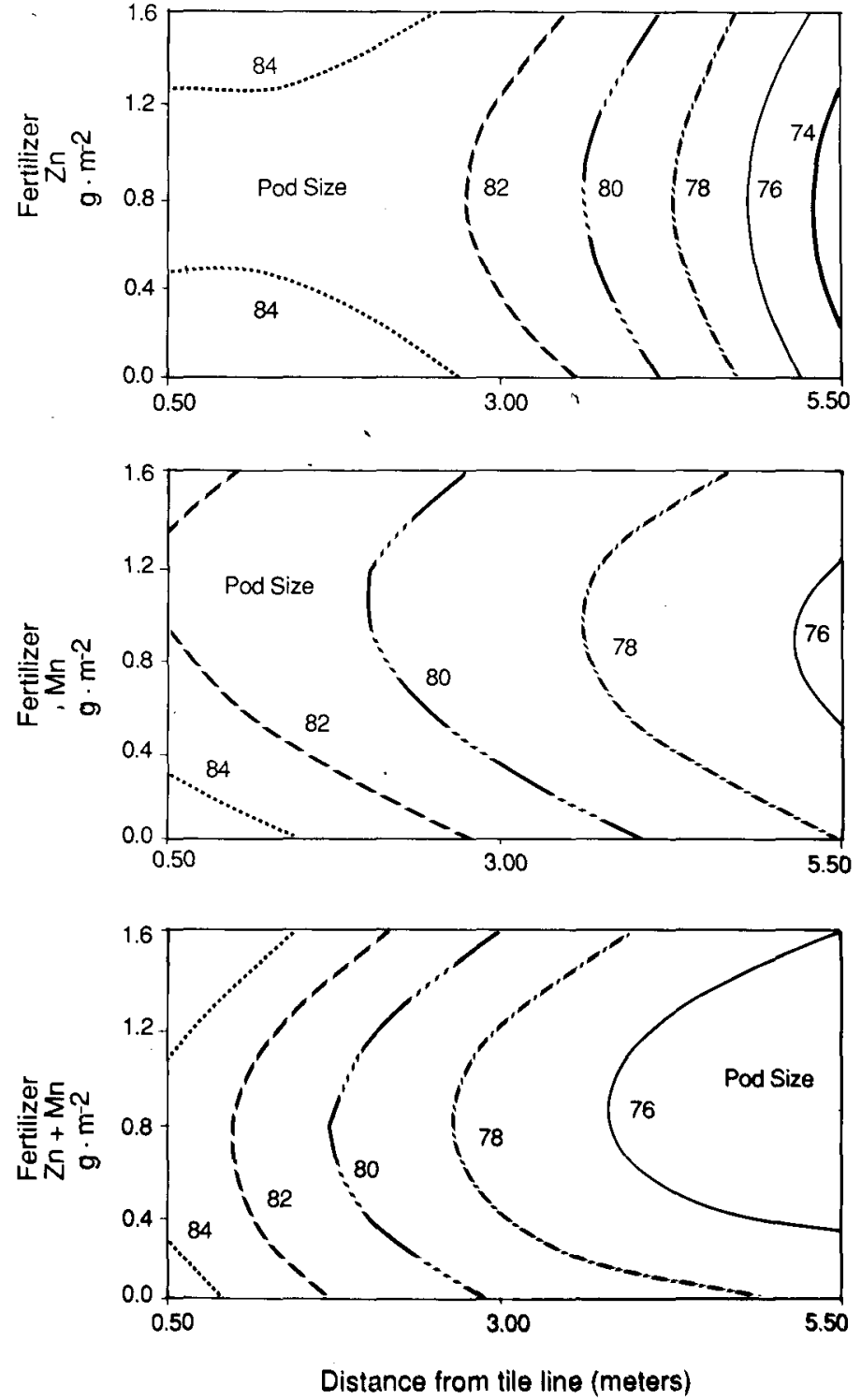

Fig. 4. Size of pods isoquants (percent of pods sieve-size 4 and under) for interaction of rates of $\mathrm{Zn}$ from $\mathrm{ZnSO}_{4}$ and $\mathrm{Mn}$ from $\mathrm{MnSO}_{4}$ (grams of $\mathrm{Zn}$ and $\mathrm{Mn} / \mathrm{m}^{2}$ ) and for distance from the tile line (m) (see Table 7).

$\mathrm{Zn} / \mathrm{m}^{2}$ was required when $\mathrm{Zn}$ and $\mathrm{Mn}$ were applied together (Fig. 1). At a distance of 2 to $3 \mathrm{~m}$ from the tile lines, a rate of
$0.4 \mathrm{~g}$ of $\mathrm{Zn} / \mathrm{m}^{2}$ maintained a level of $24 \mu \cdot \mathrm{g}$ of $\mathrm{Zn} / \mathrm{g}$ dry weight in the leaf blades from applications of $\mathrm{Zn}$ alone or with $\mathrm{Mn}$ (Fig. 1). When no $\mathrm{Zn}$ was applied or Mn was applied alone, the $\mathrm{Zn}$ concentration in the blades increased from $<16 \mu \mathrm{g}$ of $\mathrm{Zn} / \mathrm{g}$ dry weight at $0.5 \mathrm{~m}$ from tile lines to $20 \mu \mathrm{g} \cdot \mathrm{g}^{-1}$ dry weight at a distance of $3 \mathrm{~m}$ and maintained that concentration to a distance of $5.5 \mathrm{~m}$. Therefore, the increase in soil $\mathrm{Zn}$ did affect the $\mathrm{Zn}$ concentration in the leaf blade, but the increase was not great enough to raise the concentration in the leaf blade to an adequate level.

Increasing rates of $\mathrm{MnSO}_{4}$ fertilizer caused an increase in the concentration of $\mathrm{Mn}$ in the leaf blades (Table 3). Zinc fertilizer had no effect on the concentration of Mn. The concentration of $\mathrm{Mn}$ in the leaf blades as a function of rates of $\mathrm{MnSO}_{4}$ and distance from the tile lines showed that the concentration of $\mathrm{Mn}$ in the leaf blades was most dependent on distance (Fig. 2, Table 5).

Applications of $\mathrm{Zn}$ and Mn fertilizers together did not lead to an increase in the concentration of Mn over the tile lines as much as did an application of Mn fertilizer alone. A rate of $>1.6 \mathrm{~g}$ of $\mathrm{Mn} / \mathrm{m}^{2}$ was required to obtain a concentration of 60 $\mu \cdot g$ of $\mathrm{Mn} / \mathrm{g}$ dry weight in the leaf blade at $0.5 \mathrm{~m}$ from the tile lines when fertilizer $\mathrm{Zn}$ and $\mathrm{Mn}$ were applied together. When Mn fertilizer was applied alone, a rate $<0.8 \mathrm{~g}$ of $\mathrm{Mn} / \mathrm{m}^{2}$ was required to obtain the same concentration at $0.5 \mathrm{~m}$ from the tile lines (Fig. 2).

Soil test results showed that soil Mn was higher at $0.5 \mathrm{~m}$ from the tile lines and decreased with distance (Table 1), whereas the plant revealed that high rates of $\mathrm{Mn}$ fertilizer were required to increase the concentration of $\mathrm{Mn}$ in the leaf blade over the tile lines (Fig. 2). When no Mn fertilizer was applied, or $\mathrm{Zn}$ fertilizer was applied alone, the concentration of $\mathrm{Mn}$ in the leaf blade increased from $<40 \mu \mathrm{g}$ of $\mathrm{Mn} / \mathrm{g}$ dry weight at $0.5 \mathrm{~m}$ from the tile lines to $\approx 70 \mu \mathrm{g}$ of $\mathrm{Mn} / \mathrm{g}$ dry weight at greater distances from the tile lines.

Yield. The yield of pods as a function of distance from the tile lines and of rates of $\mathrm{ZnSO}_{4}$ showed yields were affected by distance, rate, and distance $\times$ rate interaction (Fig. 3, Table 6). Application of rates of $\mathrm{MnSO}_{4}$ showed no significant effects of distance or rate on yield of pods (Fig. 3, Table 6). When $\mathrm{ZnSO}_{4}$ and $\mathrm{MnSO}_{4}$ were applied together, yields were affected by distance from the tile lines (Fig. 3, Table 6).

Yield of pods was more affected by $\mathrm{Zn}$ than by Mn. Zinc and manganese applied together elicited a response similar to that of applications of $\mathrm{Zn}$ only (Fig. 3). The highest yield from applications of $\mathrm{Zn}$ only occurred at a distance of $3 \mathrm{~m}$ from the tile lines with 0.5 to $0.7 \mathrm{~g}$ of $\mathrm{Zn} / \mathrm{m}^{2}$. Yields decreased in both 
directions from there (Fig. 3). The addition of Mn to the $\mathrm{Zn}$ produced a yield response that covered a wider area than that of $\mathrm{Zn}$ alone, with high yields obtained $<2 \mathrm{~m}$ from the tile line. Rates of $1.2 \mathrm{~g}$ of each $\mathrm{Zn}$ and $\mathrm{Mn}$ were required to produce the high yields near the tile lines. High rates of $\mathrm{Zn}$ only or $\mathrm{Zn}$ plus Mn decreased yields at distances beyond $3 \mathrm{~m}$ (Fig. 3).

Size of pods. No significant effects of distance from tile lines or rates of $\mathrm{Zn}$ and $\mathrm{Mn}$ fertilizers on pod size were noted (Table 7), although a trend of increasing pod size with distance was indicated (Fig. 4).

Drainage. Precipitation during the growing season for the 2 years was above average, with 302 and $226 \mathrm{~mm}$ from planting to harvesting for 1986 and 1987, respectively, with the average being 168. $\mathrm{mm}$ for the period involved (Vittum et al., 1983). As a result, there were periods of excess water (Peck et al., 1989). The high yields obtained midway between the tile lines and at $6 \mathrm{~m}$ may in part have been due to good drainage. The soil over the tile lines may have been too calcareous to produce high yields, while soil farther away from the tile lines was more poorly drained, thus probably limiting yields. Distance from the tile lines and rate of fertilizer $\mathrm{Zn}$ and $\mathrm{Mn}$ had no effect on plant stand and no significant interactions were present.

Twenty years after installation, the effects of the highly calcareous subsoil backfilled into the trench over the tile lines were still very prominent, as shown by soil and plant analysis. The effect extends 2 to $3 \mathrm{~m}$ in each direction laterally from the sides of the tile lines. The growth and yield of the snap bean plants can be improved over and near the tile lines by the addition of both $\mathrm{Zn}$ and $\mathrm{Mn}$ fertilizer in the band at planting time. However, it appears that the calcareous subsoil over and near the tile lines will still prevail for years to come, and should be recognized as a factor that affects the concentrations of elements in the plant tissues, as well as limiting yield and delaying maturity of the crop.

\section{Literature Cited}

Bradfield, R. 1941. Calcium in the soil: I. Physico-chemical relations. Soil Sci. Soc. Proc. 6:8-15.

Cline, Marlin G. 1961. Soils and soil associations of New York. Cornell Univ. Agr. Expt. Sta. Bul. 995.

Goodman, A.M. 1953. Farm drainage. Cornell Univ. Agr. Expt. Sta. (Ithaca) Ext. Bul. 875.

Greweling, T. and M. Peech. 1965. Chemical soil tests. Cornell Univ. Agr. Expt. Sta. (Ithaca) Bul. 960.
Greweling, T. 1976. Chemical analysis of plant tissue. Cornell Univ. Agr. Expt. Sta. (Ithaca) Search Agr. 6.

Jackson, T.L., J. Hay, and D.P. Moore. 1967. The effect of $\mathrm{Zn}$ on yield and chemical composition of sweet corn in the Willamette Valley. J. Amer. Soc. Hort. Sci. 91:462-471.

Jones, L.A. 1952. Farm drainage. USDA Farmer's Bul. 1046.

Krauskopf, K.B. 1967. Geochemistry of micronutrients, p. 7-40. In: J.J. Mortvedt, F.M. Giordano, and W.L. Lindsay (eds.). Micronutrients in agriculture. Soil Soc. Amer. Madison, Wis.

MacDonald, G.E. and N.H. Peck. 1976. Border effect in a long-term fertility experiment. Agron. J. 68:530-532.

.MacDonald, G.E., N.H. Peck, and M.T. Vittum. 1978. Relationship between ammonium acetate-acetic acid and Morgan's solution for determining extractable $\mathrm{P}, \mathrm{K}, \mathrm{Ca}$, and $\mathrm{Mg}$ in soils derived from calcareous glacial till. Comm. Soil Sci. Plant Anal. 9(8):717-728.

Mohebbi, S. and R.L. Mahler. 1988. The effect of soil pH manipulation on chemical properties of an agricultural soil from northern Idaho. Comm. Soil Sci, Plant Anal. 19(15):1795-1812.

Ohki, K. 1977. Critical zinc levels related to early growth and development of determinate soybeans. Agron. J. 69:969-974,

Ohlrogge, A.J. 1954. Plot border effects in a liming experiment. Agron. J. 46:241-242.

Peck, N.H. and J.P. Van Buren. 1975. Plant responses to concentrated superphosphate and potassium chloride fertilizers. V. Snap bean (Phaseolus vulgaris var. humilis). New York State Agr. Expt. Sta. (Geneva) SEARCH 5(2):1-32.

Peck, N.H., G.E. MacDonald, M.T. Vittum, and D.J. Lathwell. 1976. Effects of concentrated superphosphate and potassium chloride on residual available $\mathrm{P}, \mathrm{K}$, and $\mathrm{Cl}$ in three depths of soil derived from calcareous glacial till. Agron. J. 68:504-507.

Peck, N.H., G.E. MacDonald, and A.V. Gardner. 1989. Snap bean plant responses. Sources and rates of nitrogen and potassium fertilizers. J. Amer. Soc. Hort. Sci. 24(4):619-623.

Piggot, T.J. 1986. Plant analysis: an interpretation manual, p. 153. In: D.J. Reuther and J.B. Robinson (eds.). Inkata, Melbourne, Australia.

Secor, W., E.A. Carlton, and J. Lamb. 1947. Physical land conditions of the fruit breeding farm at the New York State Experiment Station, Geneva, N.Y. New York State Agr. Expt. Sta. (Geneva) Tech. Bul. 279:1-30.

Tisdale, S.L. and W.L. Nelson. 1966. Soil fertility and fertilizers. Macmillan, New York. p. 329-334 and 337-343.

Vittum, M.T. 1979. Trends in vegetable culture: past, present and future. HortScience 14(3):345-349.

Vittum, M.T., G.H. Gibbs, and J. Barnard. 1983. Minimum and maximum temperatures and record periods of warm and cold, wet and dry weather at Geneva, N.Y, New York State Agr. Expt. Sta. (Geneva) Special Rpt. 47:1-26. 